\title{
PINGUICULA $\times$ GRESIVAUDANICA (LENTIBUlaRIACEAE), A NEW BUTTERWORT HYBRID FROM THE FRENCH ALPS
}

\author{
AYMERIC RocciA $\bullet$ La Terrase $•$ France $・$ aymeric.roccia@live.fr
}

Keywords: field studies: taxa: Pinguicula $\times$ gresivaudanica, French $A$ Ips

\begin{abstract}
A bstract: A new natural hybrid of Pinguicula is here reported from the French A Ips. It proceeds from the natural crossing of $P$. grandiflora $L$ am. subsp. rosea (M utel) Casper with $P$. vulgaris $L$. subsp. vulgaris. The newly recorded hybrid is named Pinguicula $\times$ gresivaudanica because of the region where it has been discovered. The characters distinguishing this hybrid from other taxa are described, together with figures, a distribution map and a table. Fertility and chromosome number were also studied, supporting the hybrid nature of this plant.
\end{abstract}

\section{Introduction}

The butterwort genus (P inguicula L., Lentibulariaceae) is composed of approximately 100 species (Rodondi et al. 2010; Y IIdırım et al. 2012). They occur in the Old World from Europe to Japan via Siberia. In A merica, they can be found in A laska, Canada, the Rocky M ountains, the Andes, and Tierra del Fuego. A few species can also be found in southeastern USA, one in Himalaya, and two in northern A frica. B ut the centers of diversity of this genus are found in $\mathrm{M}$ exico, $\mathrm{Cuba}$, and around the M editerranean Sea (Steiger 1998; Y Ildıım et al. 2012). H owever, only two natural hybrids have been described so far: Pinguicula $x$ hybrida Wettst. (Wettstein 1919) and P. X scullyi Druce (D ruce 1922).

Pinguicula $\times$ scullyi was described in 1922 by Druce from Irish material. It is a hybrid between the large-flowered butterwort (P. grandiflora Lam. subsp. grandiflora) and the common butterwort (P. vulgaris L.) that has also been recorded from A ndorra (Partrat 2001) and the A lps (pers. obs.). Pinguicula vulgaris is a circumboreal species, quite common in suitable habitats in A laska, Canada, northern USA, Iceland, Europe, and Russia. Pinguicula grandiflora only occurs in western Europe, from northern Spain, France (Pyrénées, M assif Central, J ura, and the Alps) and Ireland. It is also known from two locations in Switzerland and has been introduced in Britain (Heslop-Harrison 2004). In addition, it has recently been discovered in Northern Italy (Compostella et al. 2010). This species shows a great morphological variation and several infraspecific taxa have been described: i) P. grandiflora Lam. subsp. rosea (M utel) Casper (Casper 1966), the pink-flowered butterwort occurring in the Isère, Savoie, and Haute Savoie departments in France (Fig. 1), ii) P. grandiflora Lam. f. pallida (Gaud.) Casper (Gaudin 1828), a light-blue flowered form native to the J ura M ountains, and iii) P. grandiflora L am. f. chionopetra N elson (Nelson 1993), a white-flowered form originating from Ireland and the Pyrénées (pers. comm.). Although these infraspecific taxa are known to occur sympatrically with $P$. vulgaris subsp. vulgaris in certain locations, only natural hybrids with $P$. grandiflora subsp. grandiflora have been recorded so far.

During fieldtrips to observe P. grandiflora subsp. rosea in its habitat, some unusual butterworts with larger and bluish flowers were found always growing sympatrically. Evidence is here provided for the hybridogenic origin of this odd plant and it is described under the name P inguicula $\times$ gresivaudanica Roccia, hybrida nova. 
Vegetative and floral morphology and morphometry: morphological (shape and color of leaves, calyx lobes, spur, corolla, and stigma) and morphometric (leaf number, length and width, scape number and length, calyx lobe size, spur length, corolla length and opening angle, corolla lobe length and width) characters were analyzed in habitat for 15 individuals. M easurements are presented as mean value \pm standard deviation (Table 1 ).

Chromosome number: chromosomes were counted on plates prepared as described in Casper \& Stimper (2007). Root tips were treated with $0.002 \mathrm{M} \mathrm{8-hydroxyquinoline} \mathrm{for} 1.5 \mathrm{~h}$ at $14^{\circ} \mathrm{C}$ and fixed in ethanol:acetic acid (3:1) for $4 \mathrm{~h}$ at $4^{\circ} \mathrm{C}$. They were then hydrolyzed in $2 \mathrm{M} \mathrm{HCl}$ for $10 \mathrm{~min}$ at $60^{\circ} \mathrm{C}$. R oot tips were water rinsed and squashed on glass slides. Chromosomes were stained with carmine acetic acid (50 $\mathrm{ml}$ acetic acid, $50 \mathrm{ml}$ water and $4 \mathrm{~g}$ carmin powder) and counted using a light microscope.

\section{Results}

Pinguicula $\times$ gresivaudanica Roccia, hybrida nova P. grandiflora Lam. subsp. rosea (M utel) Casper $X P$. vulgaris $L$. subsp. vulgaris.

Differs from Pinguicula grandiflora subsp. grandiflora in having a lavender corolla, corolla lobes as long as wide, a spur curved downwards and slightly shorter than in P. grandiflora subsp. grandiflora (proportionally to the full corolla length), a throat macula rounded in shape, outer corolla tube surface whitish, and above all in being sterile.

Description: perennial rosette-forming herb with numerous fibrous roots, forming hibernacula during winter. Summer leaves 5-7, obovate-oblong, obtuse, 6-8 $\times 2-3.5 \mathrm{~cm}$, flat on the ground, with entire and slightly involute margins, the upper surface covered with mucilaginous glands. Scapes (1-) 2-4 (-5), 10-18 cm in length, green, from sparsely glandular at the base to densely glandular just below the flower. Flowers (26-) 30-34 (-36) mm in length (spur included). Calyx pentamerous bilabiate, glandular; upper lip with 3 lobes, divided nearly to the base, obovate to triangular, acute to subobtuse, (3-) 3.5-4.5 (-5) $\mathrm{mm}$ in length; lower lip with 2 lobes, united from the base for (1/4-) $1 / 3(-1 / 2)$ of their length, obovate to triangular, acute to subobtuse, $3.5-4.5 \mathrm{~mm}$ in length. Corolla bilabiate, lavender to Persian blue (see Table 1 for color), (26-) 30-34 (-36) mm in length; upper lip with 2 lobes, suborbicular, approximately as long as wide, 6-8 $\times 6-8 \mathrm{~mm}$; lower lip with 3 lobes, somewhat wavy and slightly overlapping, suborbicular, nearly as wide as long, the lateral ones 8-10 $\times 8-10 \mathrm{~mm}$, the median lobe bigger, 10-12 × 10-12 mm; palate hairy, bearing a large white rounded spot, with violet veins; throat densely hairy, white with 2 dark spots at the base; spur approximately $3 / 10$ of the total corolla length, (7-) 8-11 (-11.5) mm in length, darker than the corolla (columbine), cylindrical, curved downwards. Capsule never observed (drying before maturation). Seeds never observed (presumed sterile). Flowering from the second half of $M$ ay to the first half of J une. (Fig. 2 and 3$)$

Holotype: Crêt de Chazay (Les A drets, Isère, France), 26 M ay 2012, Roccia, M H N Gr.2012.35958 (GRM)

Paratype: Tourbière de la Grande Côte (Chapareillan, Isère, France), 28 May 2012, Roccia, MHNG r.2012.35960 (GRM)

Etymology: the epithet "gresivaudanica" refers to the Grésivaudan valley along which the hybrid has been discovered.

Chromosome number: $2 n=\sim 40-50$ 


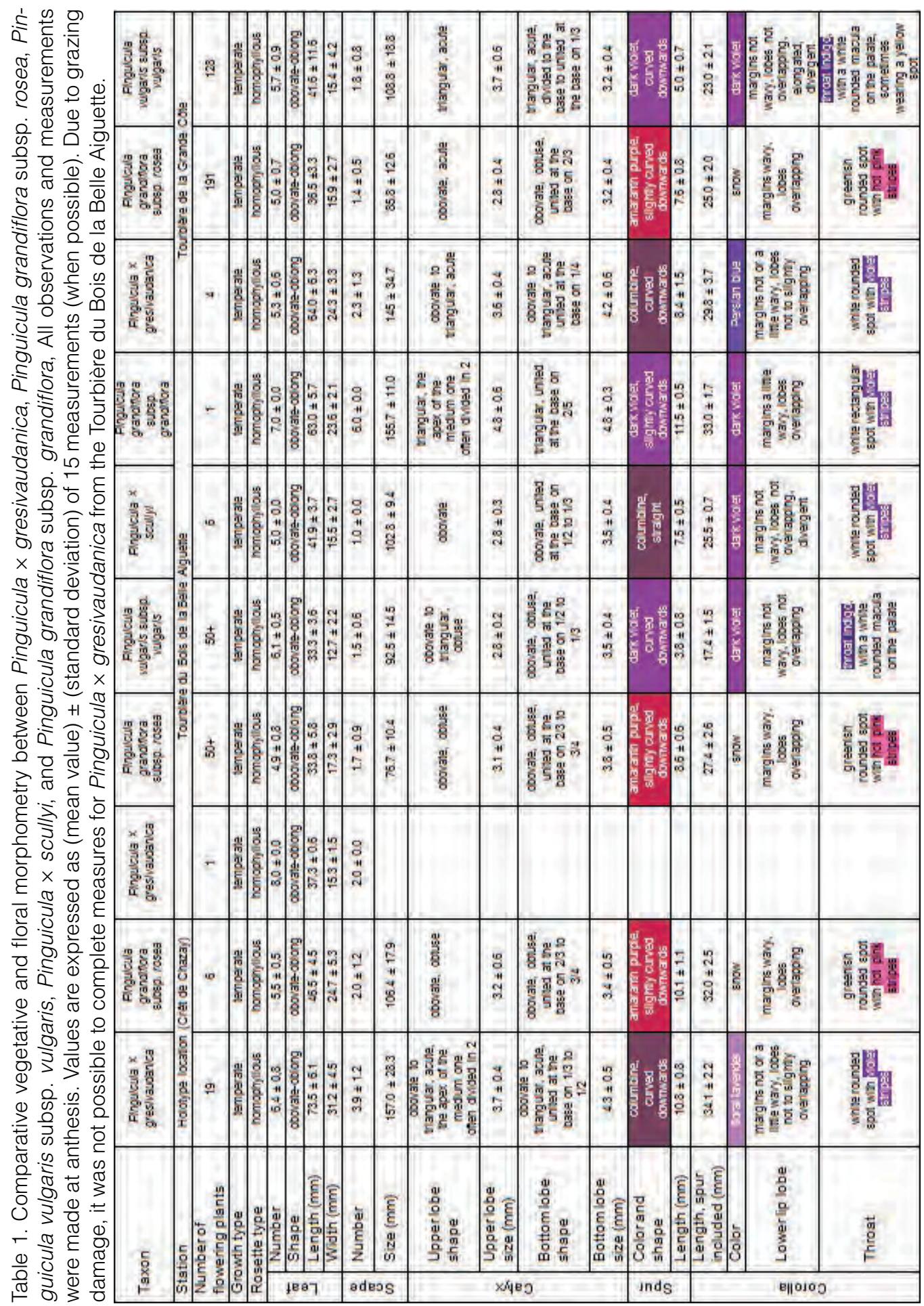




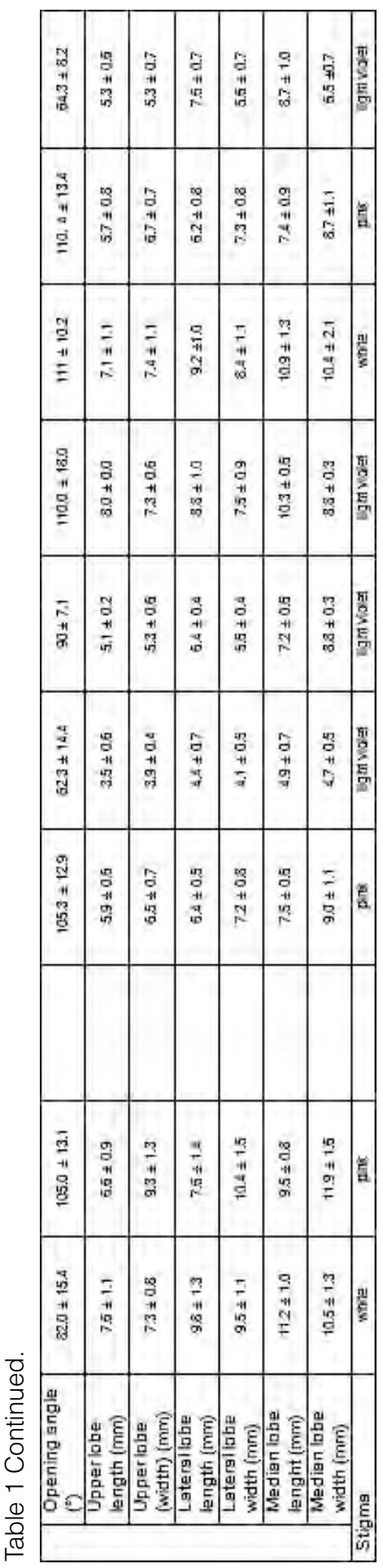

Discussion

Distribution: Pinguicula $\times$ gresivaudanica occurs in the Chartreuse and B elledonne mountain ranges where $P$. grandiflora subsp. rosea and $P$. vulgaris subsp. vulgaris can also be found (Fig. 1). The hybrid has only been found so far in three localities. The Haute-Savoie department is also home to $P$. grandiflora subsp. rosea and $P$. vulgaris. Their hybrid may also be present there.

$\mathrm{H}$ abitat and ecology: Pinguicula $\times$ gresivaudanica grows on calcareous seepages covered by mosses and in alkaline bogs. However, it is always found in shady places, well covered by trees, which is not a suitable lightning environment for most European butterworts (Fig. 2D).

A t the type location, $P . \times$ gresivaudanica and $P$. grandiflora subsp. rosea grow in Hypnaceae mosses. This seepage is located at the edge of a spruce plantation and the butterworts share their habitat with Carex hostiana DC. (Cyperaceae), Aquilegia vulgaris L. (Ranunculaceae), Rubus sp. (Rosaceae), Geranium robertianum L. subsp. robertianum (Geraniaceae), Ligustrum vulgare L. (Oleaceae), Lonicera xylosteum L. (Caprifoliaceae) and some seedlings of Acer pseudoplatanus L. (A ceraceae).

At the Tourbière du Bois de la Belle Aiguette bog, $P . \times$ gresivaudanica grows along a small stream under the shade of Betula pendula Roth (Betulaceae) and is competing with Caltha palustris L. (Ranunculaceae). P inguicula grandiflora subsp. rosea and $P$. vulgaris subsp. vulgaris can be found along the same stream but in sunnier places along with Carex davalliana Sm., C. nigra (L.) Reichard (Cyperaceae), Viola palustris L. (Violaceae) and Saxifraga stellaris L. (Saxifragaceae) among others. Pinguicula grandiflora subsp. grandiflora and P. x scullyi are growing in higher parts of the bog where Sphagnum species (Sphagnaceae) begin to colonize the peat surface. However, grazing has greatly reduced the numbers of plants of $P . x$ gresivaudanica and $P$. grandiflora subsp. grandiflora, resulting in incomplete measurements in Table 1 for both taxa. 

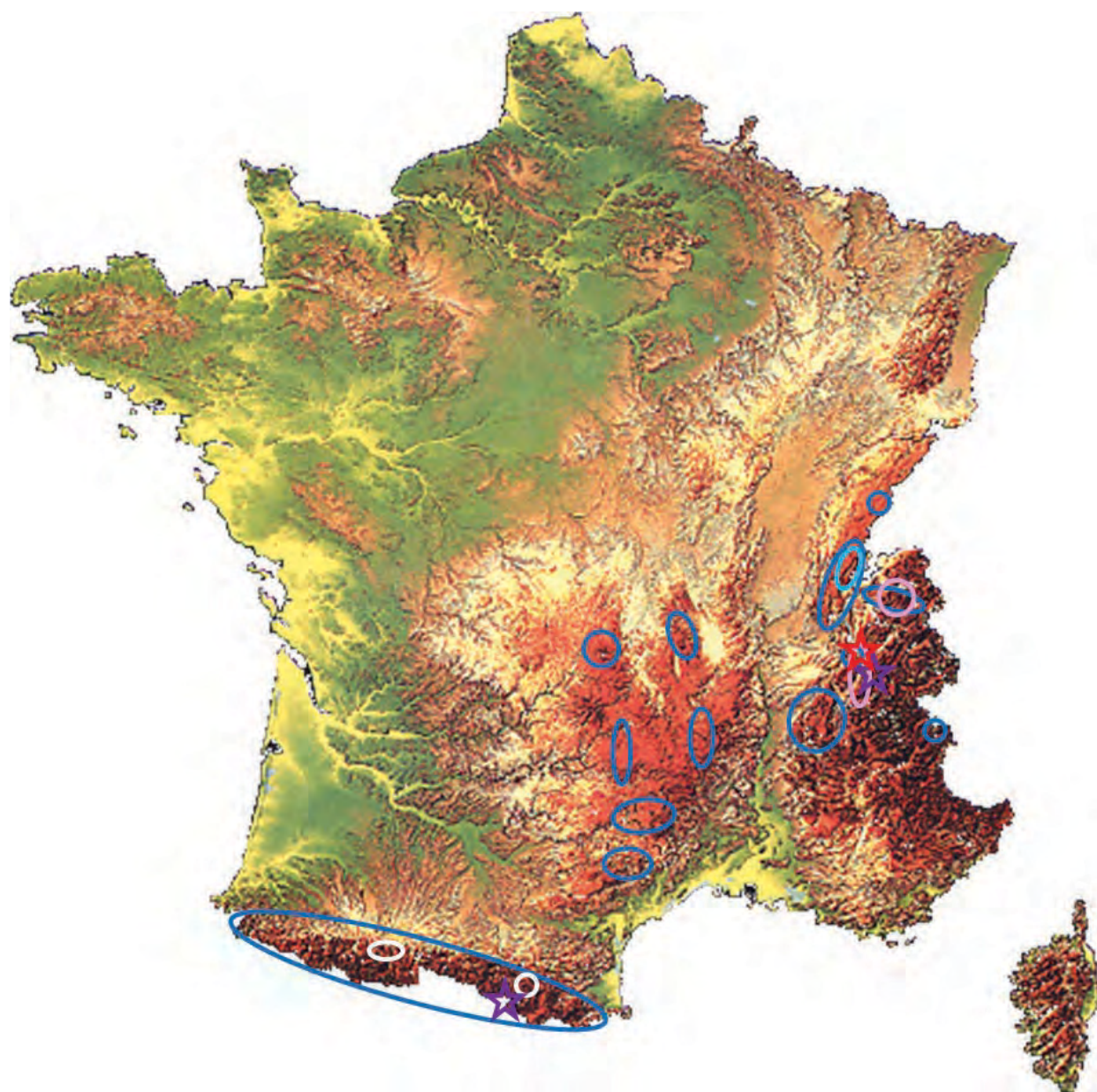

Figure 1: Distribution of Pinguicula grandiflora subsp. grandiflora (blue circles), $P$. grandifora subsp. rosea (pink circles), $P$. grandiflora f. pallida (light blue circle), $P$. grandifloraf. chionopetra (white circles), P. $\times$ scullyi (violet stars), and $P . \times$ gresivaudanica (red star).

At the Tourbière de la Grande Côte bog, P . x gresivaudanica grows along a little stream among Carex davalliana Sm. (Cyperaceae) and Equisetum sp. (Equisetaceae), under pines and some willows and Amelanchier ovalis M edik (Rosaceae). Pinguicula grandiflora subsp. rosea and P. vulgaris subsp. vulgaris can be found in sunnier places, in a Caricion davallianae bog, sometimes dominated by Phragmites australis (Cav.) Steud. (Poaceae). Pinguicula alpina L. is also found growing near this site.

Relationship: The hybrid is morphologically close to P. X scullyi and P. grandiflora subsp. grandiflora. B oth hybrids have long been mistaken for $P$. grandiflora subsp. grandiflora, explaining why $P . \times$ gresivaudanica remained unknown even if its localities were well botanized.

The hybrids of the two subspecies of P. grandiflora with P. vulgaris can be distinguished at first sight from their respective parent species by a corolla angle that is intermediate between both 

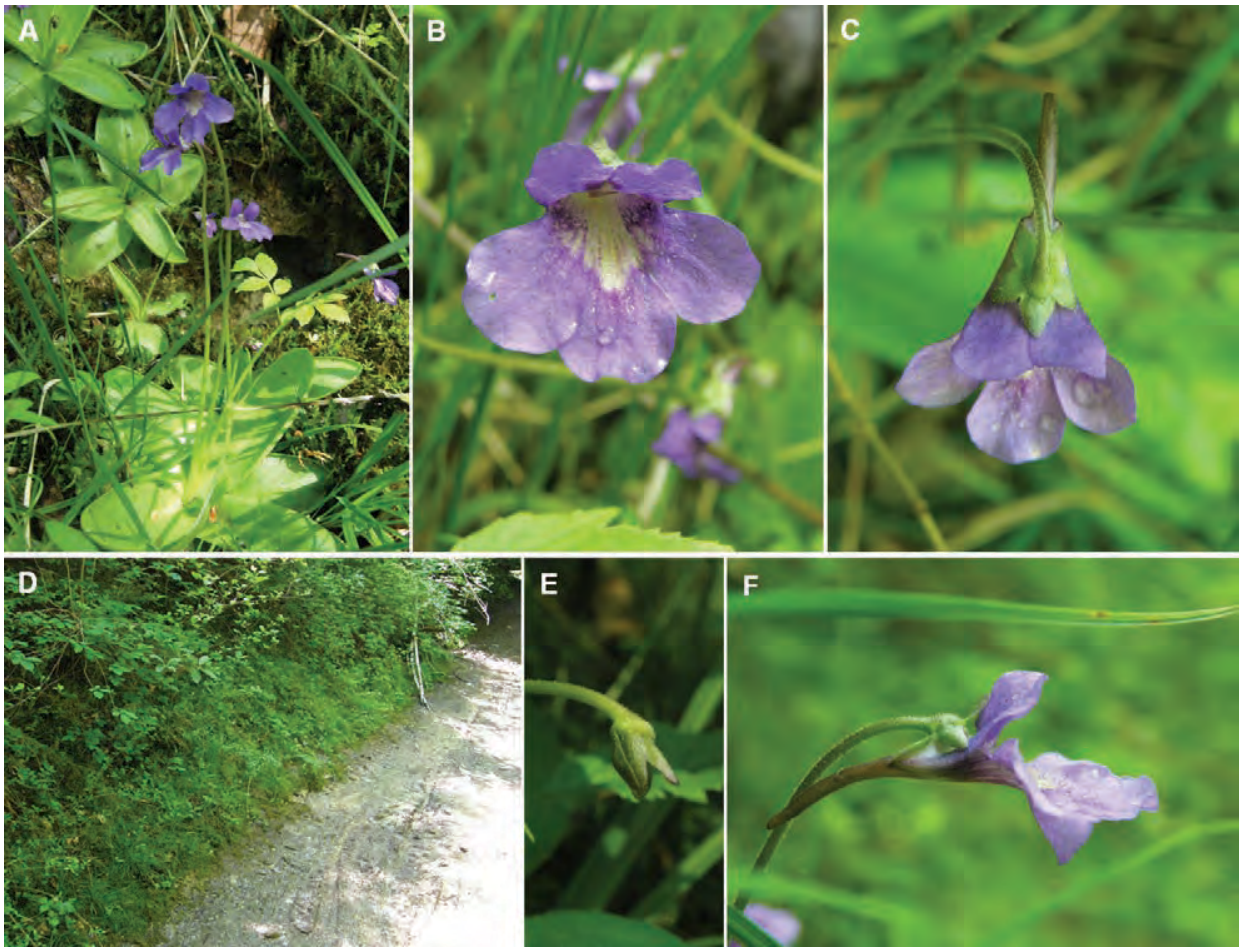

Figure 2: Pinguicula $\times$ gresivaudanica. A: habit; B: front view of the flower; C: view from above; D: habitat; E: fruit at maximum development; F: lateral view of the flower. All pictures were taken at the type location.

A

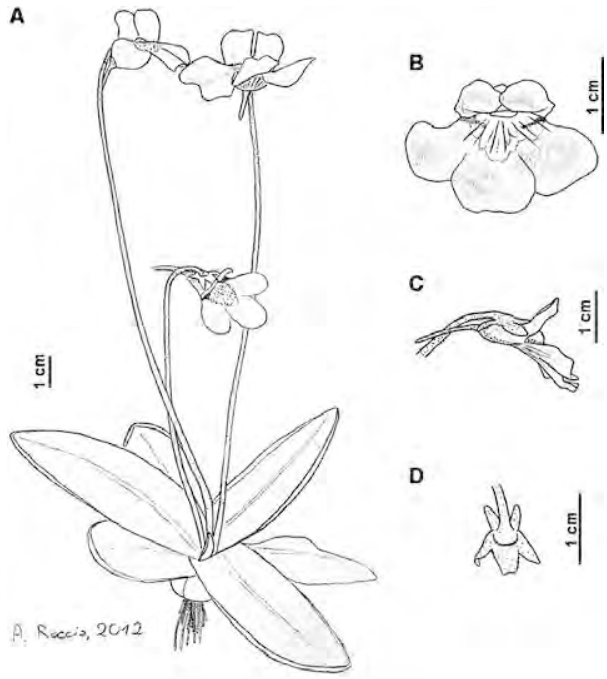

Figure 3: Pinguicula $\times$ gresivaudanica from the type location. A: habit; $\mathrm{B}$ : front view of the flower; C: lateral view of the flower; D: calyx. parents (Fig. 4 and Table 1). They bear a welldefined palate macula similar to the one of $P$. grandiflora subsp. grandiflora but it is rounded in the hybrids and rectangular in this subspecies. It is noteworthy that $P . \times$ gresivaudanica has corolla lobes that are constantly as long as wide whereas they are constantly wider than long in P. grandiflora subsp. rosea and longer than wide for the lower lip lobes in $P$. grandiflora subsp. grandiflora and P. vulgaris subsp. vulgaris. The spur of $P . \times$ gresivaudanica is also more curved downwards than in P. grandiflora, a character reminiscent of the spur found in $P$. vulgaris. Pinguicula $x$ scullyi has flowers of a dark violet such has those of Pinguicula vulgaris subsp. vulgaris whereas $P . \times$ gresivaudanica has a lavender to Persian blue corolla, quite intermediate in color between $\mathrm{P}$. grandiflora subsp. rosea and P. vulgaris subsp. vulgaris. The 
outer side of the corolla tube has the same color as the corolla lobes and spur in P. X scullyi whereas it is whitish in $P . x$ gresivaudanica.

At its type location, $P . \times$ gresivaudanica grows along with a very few pale $P$. grandiflora subsp. rosea that tend to disappear because of the lack of luminosity in this shaded place. A the Tourbière du B ois de la B elle A iguette, a single plant of the hybrid was found growing behind a small birch under a pine, where it does not receive any direct sunlight. 0 nly $50 \mathrm{~cm}$ away, in direct sunlight, one can find $P$. grandiflora subsp. rosea and $P$. vulgaris subsp. vulgaris, both parents of this hybrid. N earby in this same bog, $P$. vulgaris subsp. vulgaris grows sympatrically with $P$. grandiflora subsp. grandiflora and there, some P. $\times$ scullyi can be found. At its only known site in the Chartreuse massif, namely Tourbière de la Grande Côte, $P$. $x$ gresivaudanica grows in absence of any of the putative parent species, but $P$. grandiflora subsp. rosea occurs in a bog at $20 \mathrm{~m}$ distance, and $P$. vulgaris subsp. vulgaris at $120 \mathrm{~m}$ distance. Ten years ago, $P$. grandiflora subsp. rosea was known to be much more widespread than today in this site (pers. comm.). It is possible that the hybrid once grew among the parental species and that rock movements and closure of the biotope led to the separation of the three taxa in this habitat of continuously moving screes with rapid movements.

The presence of $P$. grandiflora subsp. rosea growing sympatrically with or very close to $P . x$ gresivaudanica at the three known locations of the hybrid, supports the assumed parentage. The second assumed parental species, $P$. vulgaris subsp. vulgaris is found growing sympatrically with or close to the hybrid in two of its three known sites. It is important to note that both $P$. grandiflora subsp. rosea and $P$. vulgaris subsp. vulgaris flower at the same period in their common locations. It is very unlikely that $P$. grandiflora subsp. grandiflora is one of the parents of this hybrid instead of $P$. grandiflora subsp. rosea, as the former is not known to grow at two of the three hybrid locations whereas in the last site it grows further distant. It is noteworthy that $\mathrm{P} . \times$ scullyi is also known to

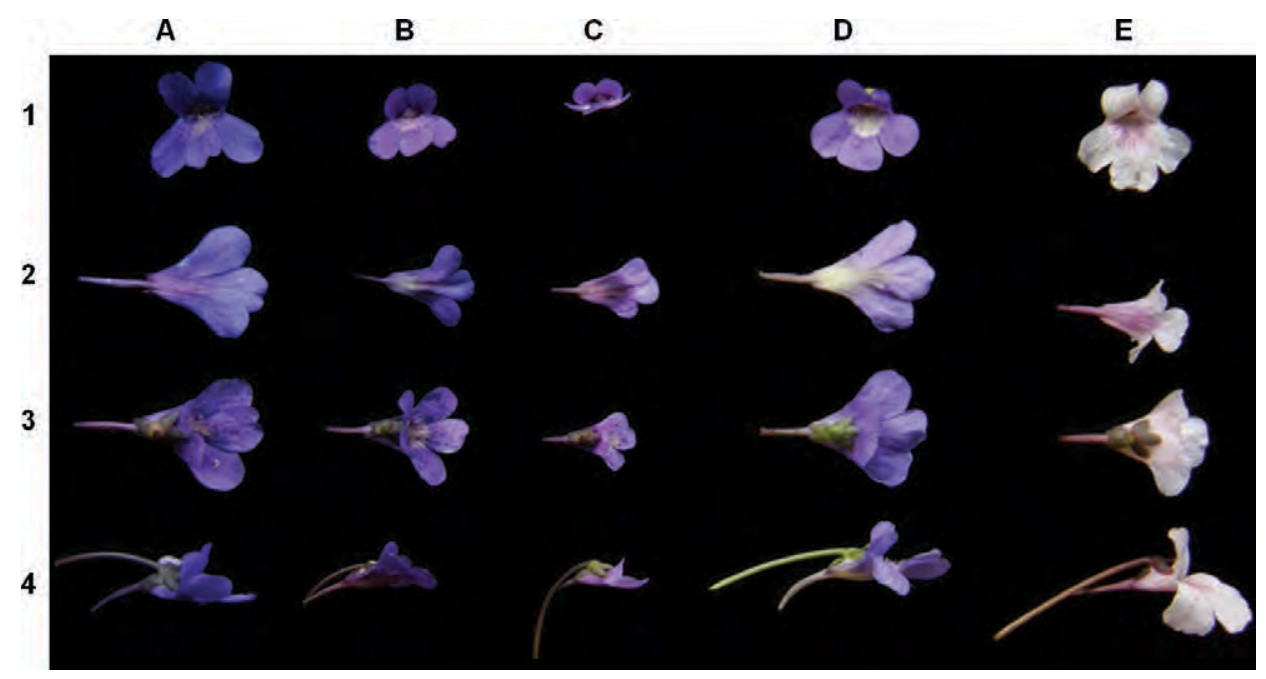

Figure 4: Comparative photographs of the studied species. Row A: Pinguicula grandiflora subsp. grandiflora; B: Pinguicula $\times$ scullyi; C: Pinguicula vulgaris subsp. vulgaris; D: Pinguicula $\times$ gresivaudanica; E: Pinguicula grandiflora subsp. rosea. Line 1: frontal view of the flower; 2: view from below; 3: view from above; 4 lateral view. All specimens are from the Tourbière du Bois de la Belle Aiguette, except Pinguicula $\times$ gresivaudanica that is from its type location. Photographs were taken according to Steiger, 1976. All flowers used for this figure are deposited in the voucher MHNGr.2012.35966. 
grow in this bog and can be distinguished from P. $x$ gresivaudanica (see above, Fig. 4 and Table 1). However, because $P . \times$ gresivaudanica occurs in shady places that are seemingly not suitable for either of the parental species, it is possible that new localities of the hybrid will be found where $P$. grandiflora subsp. rosea and $\mathrm{P}$. vulgaris subsp. vulgaris would be absent, as it begins to happen in the site in the Chartreuse range.

Sterility: Flower visitors of this plant have been studied at the type location. Small insects belonging to the bee genus $\mathrm{H}$ alictus (Halictidea) (sweet bees) were observed entering and getting out of a flower to visit another in search of nectar or pollen (Fig. 5). However, returning to the site one month later, no seedpods could be found. It seems that ovaries of this plant soon desiccate after the corolla has been shed (Fig. 6). It is not a matter of environmental conditions as P. grandiflora subsp. rosea of this site do produce mature seedpods and seeds. D uring this study, it was al so observed that $P$. $\times$ scullyi does not produce mature seedpods nor seeds while all other taxa, except $P$. $x$ gresivaudanica, at the same location do make seeds.

Cultivation specimens of the plant studied in this article were also observed for this character. Flowers were hand-pollinated but only two mature capsules out of six pollinated flowers were obtained. However, those seedpods did not contain any seeds. So it is very likely that this plant is totally sterile, not a single seed grain could be observed, neither in in situ specimens nor in ex situ hand-pollinated plants. The infertility of a hybrid between Pinguicula grandiflora and Pinguicula vulgaris was predictable as both parents have different chromosome numbers, leading in a triploid sterile hybrid.

A lthough $P$. x gresivaudanica cannot reproduce in a sexual way, it produces many plantlets by gemmae formation around the winter hibernacula. This production is even greater than in $P$. gran-
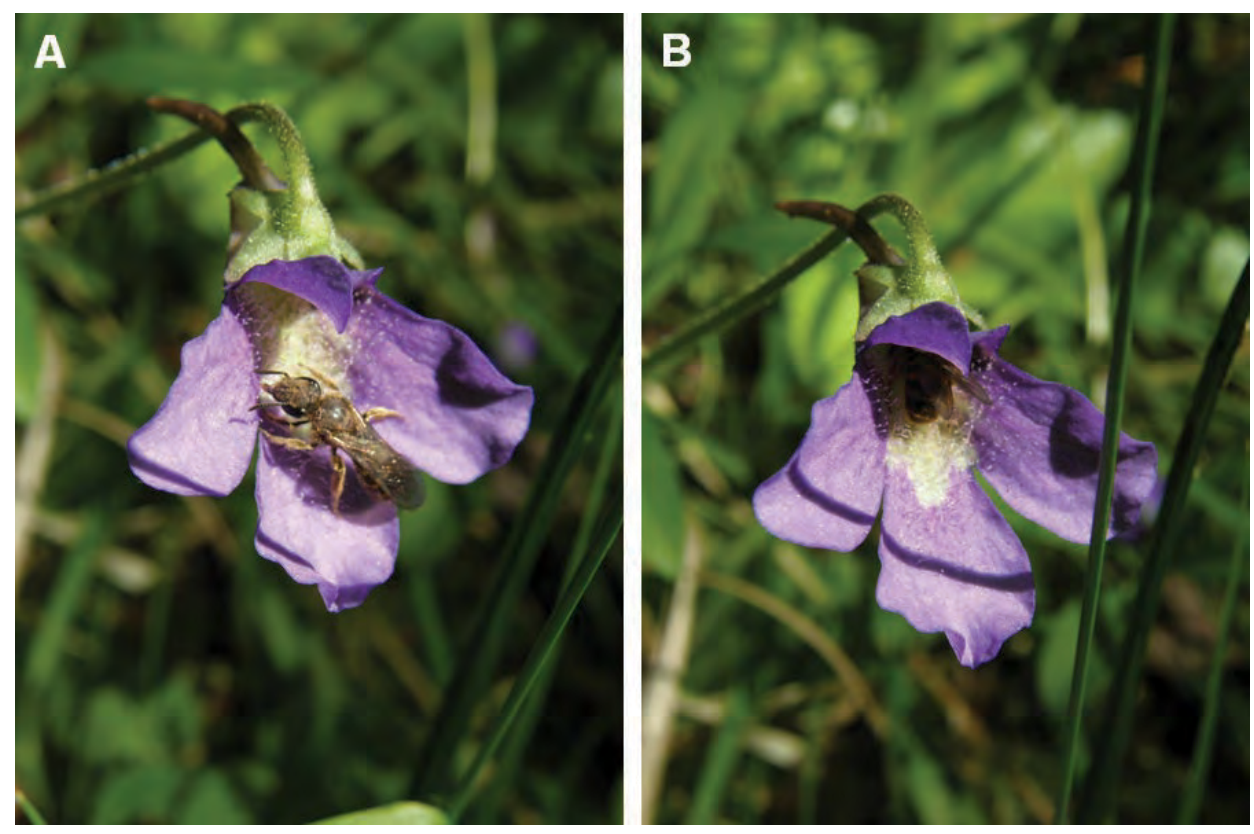

Figure 5: Flower visitor of Pinguicula $\times$ gresivaudanica. A: the Halictus $\mathrm{sp}$. on the flower lower lip after landing; B: the Halictus sp. visiting the corolla tube. Pictures were taken at the type location. 

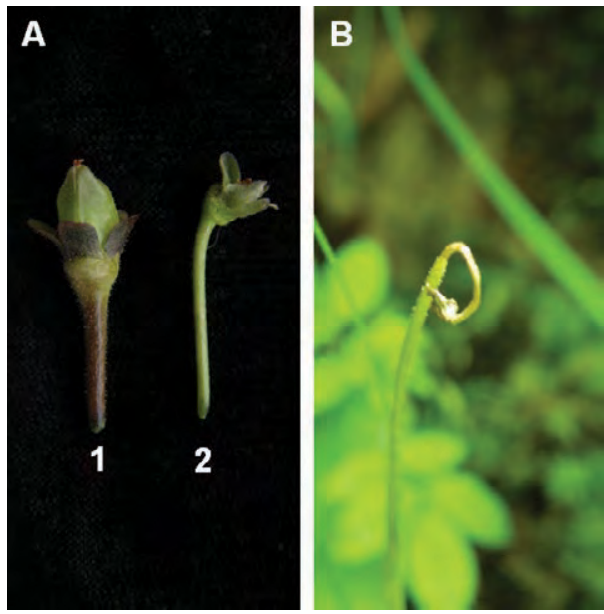

Figure 6: Different views of seedpods. A: Capsules at maximal development stage (1: Pinguicula grandiflora subsp. rosea; 2: $P . \times$ gresivaudanica), both have approximately the same age; $B$ : typical drying $P . \times$ gresivaudanica seedpod. All plants are from the type location.
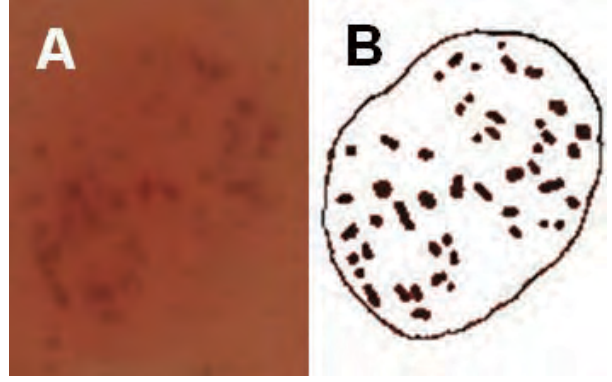

Figure 7: Karyotype of Pinguicula $x$ gresivaudanica showing 48 chromosomes. A: light microscope photograph; B: interpretation drawing.

diflora and plantlets become adult in a much shorter time than for the species (pers. obs.).

Chromosome number: The chromosome number was difficult to obtain for $P . x$ gresivaudanica due to the tiny size of the mitotic chromosomes, as in most butterwort species. However, most results gave a number between 40 and 50 (Fig. 7). The expected number for a

hybrid involving $P$. grandiflora subsp. rosea $(2 n=32$ (Casper \& Stimper 2007)) and $P$. vulgaris $(2 n=64$ (Casper $\&$ Stimper 2007)) would be of $2 n=48$. Thus, I assume that the real chromosome number of this plant is 48 . This important fact supports the hybrid origin of $P . x$ gresivaudanica.

Conservation: The total number of flowering plants of $P . x$ gresivaudanica observed in its three known locations do not exceed 50 individuals. Thus, this taxon can be considered as "Critically Endangered" (CR) D following IUCN criteria. M oreover, as it only reproduces vegetatively, it cannot pretend to colonize new habitat as easily as its parents. Logging activities may represent a real danger. A S P. $\times$ gresivaudanica tends to grow in shade, clearings in its habitat may be damageable (even if a single plant has been found in semi-shaded area in the Chartreuse site so that this taxon may survive in not so degraded conditions). In addition, grazing pressure has also shown to be damageable for P. x gresivaudanica and thus may be limited and/or plants protected from grazing.

\section{Conclusion}

The presence of $\mathrm{P}$. grandiflora subsp. grandiflora in northern French Prealps may be overestimated due to confusion with $P . \times$ gresivaudanica. This hybrid is only known from three sites but its occurrence has not been studied in Haute Savoie where it is very likely to grow. D ue to the very low number of flowering plants observed, it is considered as critically endangered following IU CN criteria.

Acknowledgements: The author would like to thank the Conservatoire Botanique National AIpin, the Parc Naturel Régional de Chartreuse and the Réserve Naturelle des Hauts de Chartreuse for permits to collect living material of protected taxa and on protected areas (arrêtés préfectoraux $n^{\circ}$ 2012-072-0045, DDT/SEEF $n^{\circ} 2012-205$ and n²012-160-0024). The author also acknowledges $R$. Stimper for giving hints on kariotype preparation, and A. Fleischmann and F. Rivadavia for advice on this article. A. Fleischmann is also thanked for the flower visitor identification. Julie D elavie, cu- 
rator of the M uséum d'Histoires Naturelles de Grenoble herbarium, is also thanked for her advices on herbarium specimens.

A ppendix

Other specimens examined:

Pinguicula grandiflora Lam. subsp. grandiflora; FRA NCE. Tourbière du Bois de la Belle A iguette (Saint Pierre d'A Ilevard, I sère, France), 16 J une 2012, Roccia, M H NG r.2012.35966 (GRM )

Pinguicula grandiflora Lam. subsp. rosea (M utel) Casper: FRANCE. C rêt de Chazay (Les A drets, Isère, France), 26 M ay 2012, Roccia, M H N Gr.2012.35959 (GRM ); Tourbière de la G rande Côte (Chapareillan, I sère, France), 28 M ay 2012, Roccia, M HNGr.2012.35961 (GRM); Tourbière du Bois de la Belle Aiguette (Saint Pierre d'Allevard, Isère, France), 16 June 2012, Roccia, M H NG r.2012.35963 (GRM); Tourbière du Bois de la Belle Aiguette (Saint Pierre d'A llevard, Isère, France), 16 J une 2012, Roccia, M H N Gr.2012.35966 (GRM ).

Pinguicula vulgaris L. subsp. vulgaris L.: FRANCE. Tourbière de la Grande Côte (Chapareillan, Isère, France), 28 M ay 2012, Roccia, M H N Gr.2012.35962 (GRM ); Tourbière du B ois de la B elle Aiguette (Saint Pierre d'Allevard, Isère, France), 16 June 2012, Roccia, M H NGr.2012.35964 (GRM ); Tourbière du B ois de la B elle A iguette (Saint Pierre d'A llevard, I sère, France), 16 J une 2012, Roccia, M H N Gr.2012.35966 (GRM).

Pinguicula $\times$ gresivaudanica Roccia: FRANCE. Crêt de Chazay (Les A drets, Isère, France), 16 June 2012, Roccia, MHNG r.2012.35966 (GRM)

Pinguicula $\times$ scullyi Druce: FRANCE. Tourbière du Bois de la Belle Aiguette (Saint Pierre d'Allevard, Isère, France), 16 J une 2012, Roccia, MHNG r.2012.35965 (GRM) ; Tourbière du Bois de la Belle Aiguette (Saint Pierre d'Allevard, Isère, France), 16 J une 2012, Roccia, MHNG r.2012.35966 (GRM)

\section{References:}

Casper, S.J. 1966. M onographie der Gattung P inguicula L. B ibliotheca B otanica 127/128: 1-209.

Casper, S.J ., and Stimper, R. 2007. Chromosome numbers in Pinguicula (L entibulariaceae): survey, atlas, and taxonomic conclusions. Plant Syst. Evol. 277: 21-60.

Compostella, C., B eretta, M ., and Caccianiga, M. 2010. Pinguicula grandiflora (Lentibulariaceae), specie nuova per la flora italiana. Informatore B otanico Italiano 42(1): 63-66.

Druce, G.C. 1922 Secretary's Report for 1922. The Botanical Society and Exchange Club of the B ritish Isles 6: 159.

Gaudin, I. 1828. Sive H istoria stirpium hucusque cognitarum in Helvetia et in tractibus conterminis aut sponte nascentium aut in hominis animaliumque usus vulgo cultarum continuata. Turici. Sumptibus Orellii, Fuesslini et Sociorum. Vol. I.

Heslop-Harrison, Y. 2004. Pinguicula L. J ournal of Ecology 92: 1071-1118.

Nelson, E.C. 1993. W hite-blossomed P inguicula grandiflora L am. (L entibulariaceae) in the Burren, County Clare, Ireland. Watsonia 19: 273-275.

Partrat, E. 2001. Pinguicula X scullyi. http://www.pinguicula.org/pages/plantes/pinguicula_x_scullyi. htm, accessed $7 \mathrm{M}$ arch 2013.

Rodondi, G., Beretta, M., and A ndreis, C. 2010. Pollen morphology of alpine butterworts (Pinguicula L., Lentibulariaceae). R eview of Palaeobotany and Palynology 162: 1-10.

Steiger, J.F. 1976. Standardized photography of P inguicula blossoms. Carnivorous Plant N ewsletter 7: 43-50. 
Steiger, J.F. 1998. Pinguicula (Lentibulariaceae): the cool climate species of the Northern hemisphere. M orphology, biology, cultivation. $2^{\text {nd }}$ International Conference of the International Carnivorous Plant Society, ICPS, Fullerton, California, USA, 1-16.

Wettstein, F. 1919. Floristische mitteilungen aus den A Ipen. Österreichische B otanische Zeitschrift LXVIII (11-12): 295-296.

Yıldırım, H., Şenol, S.G., and Pirhan, A .F. 2012. Pinguicula habilii (L entibulariaceae), a new carnivorous species from South-West A natolia, Turkey. Phytotaxa 64: 46-58.
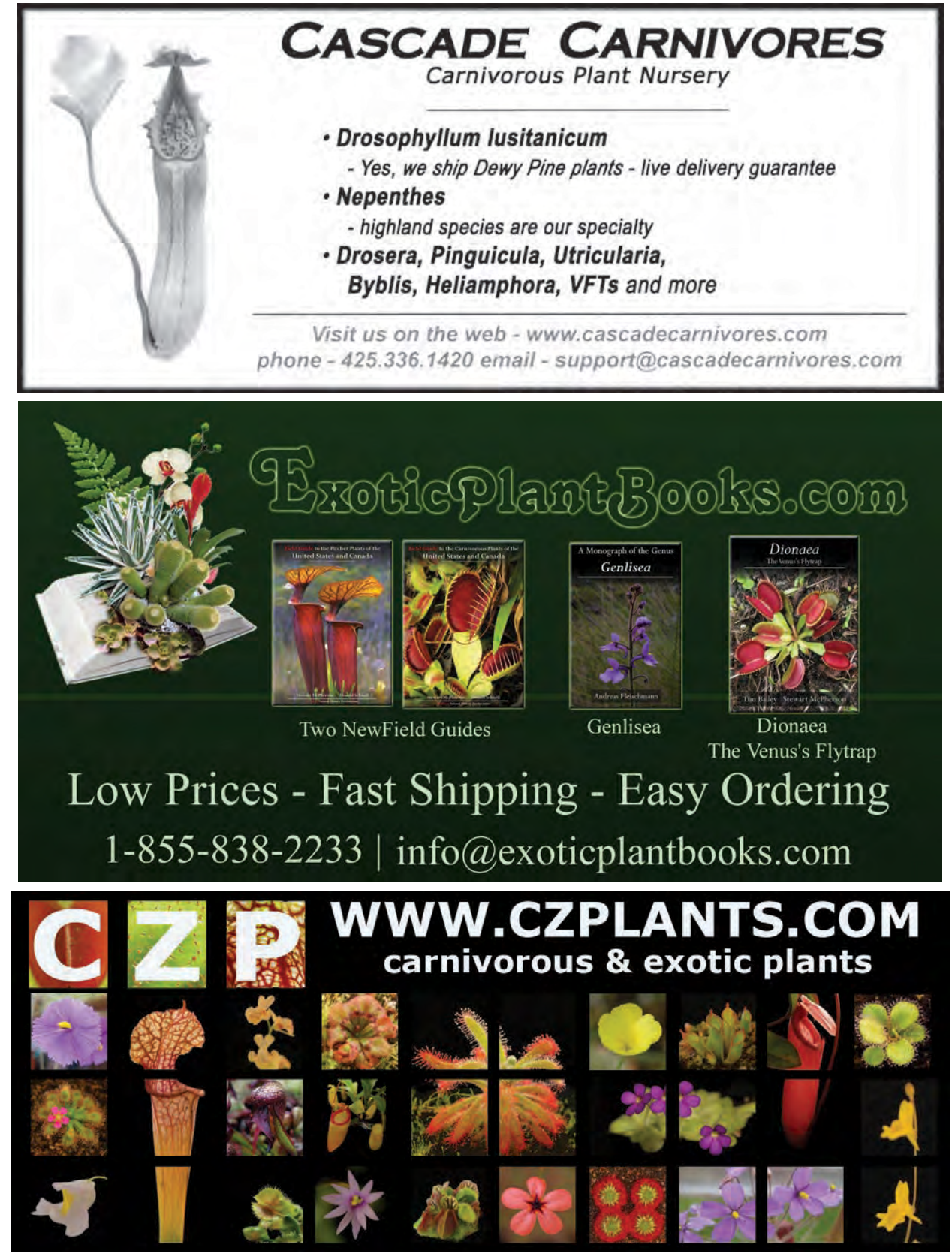


\section{CARNIVOROUS PLANT NEWSLETTER}

Journal of the International Carnivorous Plant Society

Volume 42, N 0.2

J une 2013

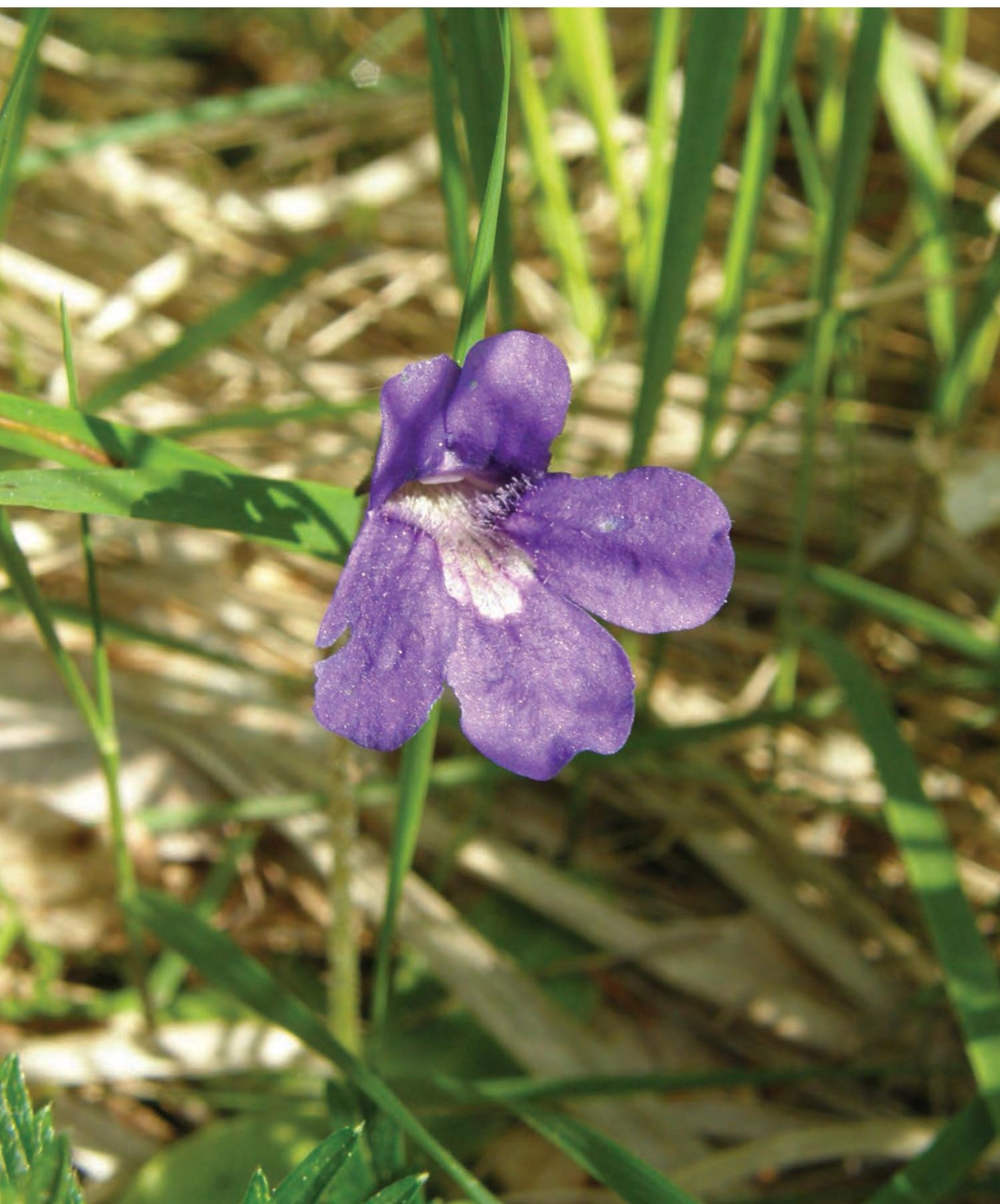




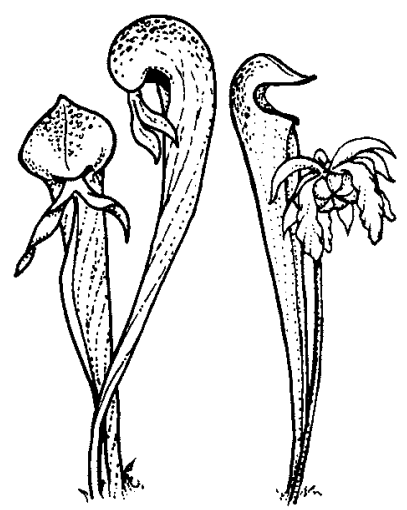

\section{CARNIVOROUS \\ PLANT \\ NEWSLETTER}

Journal of the International

Carnivorous Plant Society

www.carnivorousplants.org

Volume 42, Number 2
June 2013

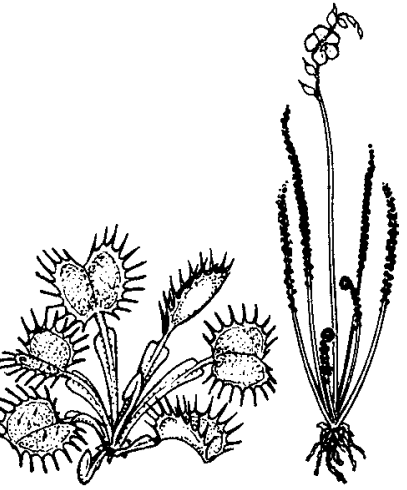

Front Cover: Pinguicula $\times$ gresivaudanica growing in the French Alps. Photo by Aymeric Roccia. Article on page 36.

Back Cover: Aldrovanda vesiculosa var. rubescens (A.Cross \& L.Adamec) from southwest Western Australia, displaying a gradient of coloration due to variable sun exposure. All individuals originate from the same maternal plant, but have been independently grown from left to right in full sun, $50 \%, 70 \%$, and $90 \%$ shade. Photo by Adam Cross. Article on page 57.

Carnivorous Plant N ewsletter is dedicated to spreading knowledge and news related to carnivorous plants. Reader contributions are essential for this mission to be successful. Do not hesitate to contact the editors with information about your plants, conservation projects, field trips, or noteworthy events. A dvertisers should contact the editors. Views expressed in this publication are those of the authors, not the editorial staff.

All correspondence regarding dues, address changes and missing issues should be sent to the Membership Coordinator at the ICPS. D o not send such correspondence to the editors. Checks for subscriptions should be made to the ICPS in US funds. Dues for 2013 are \$35 for the first year of membership; renewals are \$30 per year.

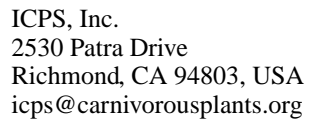

President

Vice President

Secretary/Treasurer

B oard M ember

Board M ember

B oard M ember

Board M ember

A dministrator

Seed Bank $M$ anager

CPN Editors

$M$ anaging Editor

Editor

Science Editor

Science Editor
M ichael Baldwin, michael@ carnivorousplants.org

$\mathrm{M}$ arcel van den B roek, marcel@ carnivorousplants.org

Richard M yers, richard@ carnivorousplants.org

B rian B arnes, Conservation Director, brian@ carnivorousplants.org

Richard Nunn, richardnunn@ carnivorousplants.org

Jan Schlauer, jan@ carnivorousplants.org

B ob Ziemer, bob@ carnivorousplants.org

Cindy Slezak, cindy@ carnivorousplants.org

John B rittnacher, john@ carnivorousplants.org

editor@carnivorousplants.org

B ob Ziemer

Barry Rice

Fernando Rivadavia

J an Schlauer

Date of effective publication of the M arch 2013 issue of Carnivorous Plant N ewsletter: 25 February 2013.

The ICPS is the International Cultivar Registration A uthority (ICRA) for the names of cultivated carnivorous plants according to the International Code of Nomenclature for Cultivated Plants. Send relevant correspondence to the ICPS, InC.

Carnivorous Plant N ewsletter is published quarterly in M arch, J une, September, and December by the ICPS, Inc., 2530 Patra Drive, Richmond, CA 94803, USA. Periodicals postage paid at Richmond, CA and additional mailing offices. Postmaster: Send address changes to ICPS, Inc., PM B 322, 1564-A Fitzgerald Drive, Pinole, CA 94564-2229, USA. Printed by A llen Press, Inc., 810 E. 10th Street, L awrence, KS 66044. L ogo and masthead art: Paul M ilauskas. (c) 2013 Carnivorous Plant N ewsletter. All rights reserved. ISSN \#0190-9215 